\title{
BH3-only proteins BIM and PUMA in the regulation of survival and neuronal differentiation of newly generated cells in the adult mouse hippocampus
}

\author{
EC Bunk ${ }^{1,3}$, H-G König ${ }^{1}$, T Bernas ${ }^{1}$, T Engel ${ }^{1}$, DC Henshall ${ }^{1}$, BP Kirby ${ }^{2}$ and JHM Prehn ${ }^{\star, 1}$
}

Neurogenesis persists in the adult hippocampus, where several thousand neurons are born every day. Most of the newly generated cells are eliminated by apoptosis, possibly because of their failure to integrate properly into neural networks. The BH3-only proteins Bim and Puma have been shown to mediate trophic factor withdrawal- and anoikis-induced apoptosis in various systems. We therefore determined their impact on proliferation, survival, and differentiation of adult-generated cells in the mouse hippocampus using gene-deficient mice. Wild-type, bim-, and puma-deficient mice showed similar rates of precursor cell proliferation, as evidenced by 5-bromo-2-deoxyuridine (BrdU)-incorporation. Deficiency in either bim or puma significantly increased the survival of adult-born cells in the dentate gyrus (DG) after 7 days. Consistently, we detected increased numbers of doublecortin (DCX)-positive and fewer terminal deoxynucleotidyl transferase-mediated dUTP nick end-labelled-positive cells in the DG of bim- and puma-deficient mice. Bim and puma deficiency did not change early markers of neuronal differentiation, as evidenced by BrdU/DCX double-labelling. However, BrdU/NeuN double-labelling revealed that deficiency of bim, but not puma, accelerated the differentiation of newly generated cells into a neuronal phenotype. Our data show that Bim and Puma are prominently involved in the regulation of neuronal progenitor cell survival in the adult DG, but also suggest that Bim has an additional role in neuronal differentiation of adult-born neural precursor cells.

Cell Death and Disease (2010) 1, e15; doi:10.1038/cddis.2009.13; published online 21 January 2010

Subject Category: Neuroscience

This is an open-access article distributed under the terms of the Creative Commons Attribution License, which permits distribution and reproduction in any medium, provided the original author and source are credited. This license does not permit commercial exploitation without specific permission.

In the adult brain of rats, mice, and humans, specific areas retain their neurogenic capacity and generate new cells throughout life. ${ }^{1}$ One of these areas is the subgranular zone (SGZ) of the hippocampal dentate gyrus (DG). ${ }^{2}$ Here, neuronal and glial progenitor cells as well as neurons in different stages of development and maturation are found within a structure of about three cells width. ${ }^{3,4}$ From here, the cells migrate only short distances into the granule cell layer (GCL), ${ }^{5}$ where they adopt the morphological characteristics of granule cells ${ }^{1}$ and extend axonal projections to neurons within the CA3 region. ${ }^{6}$

During this process of adult hippocampal neurogenesis, a substantial number of new cells are generated every day, but their survival remains heavily restricted by apoptotic demise. ${ }^{7}$ Within about 3 weeks after birth, almost $50 \%$ of the newly generated cells in the rat hippocampus die. ${ }^{8}$ The most prominent death rates occur in those populations that have left the cell cycle, become postmitotic, and express the markers DCX and calretinin. ${ }^{9,10}$ Similarly, high rates of apoptotic turnover of adult-generated, postmitotic cells have been observed in the olfactory bulb. ${ }^{11}$ Although the generation of new neurons and their apoptotic obliteration are working in opposite directions, these processes are believed to form a careful balance to control cell numbers in the target regions of neurogenesis. Once the cells survive $2-3$ weeks beyond their exit from cell cycle, their survival tends to remain essentially stable. $^{12}$

The mitochondrial pathway is an important determinant in the apoptosis of adult-generated cells of the DG. ${ }^{10,13}$ Most apoptotic signalling pathways culminate in the formation of pores in the mitochondrial outer membrane, a process that leads to the activation of caspase-dependent and -independent apoptosis. Proteins of the Bcl-2 family guard over the execution of apoptosis by regulating the integrity of the mitochondrial outer membrane. A key role in the initiation of mitochondrial outer membrane permeabilisation has been shown for Bax and Bak, proteins that physically constitute the release channel in the outer mitochondrial membrane. ${ }^{14}$

\footnotetext{
1Department of Physiology and Medical Physics, RCSI Neuroscience Research Centre, 123 St. Stephen's Green, Dublin 2, Ireland and ${ }^{2}$ School of Pharmacy, Royal College of Surgeons in Ireland, 123 St. Stephen's Green, Dublin 2, Ireland

${ }^{3}$ Current address: ZBME, Institute of Cell Biology, University of Muenster, Von-Esmarch-Straße 56, Münster 48149, Germany.

${ }^{*}$ Corresponding author: JHM Prehn, Department of Physiology and Medical Physics, Royal College of Surgeons in Ireland, 123 St. Stephen's Green, Dublin 2, Ireland. Tel: + 3531402 2255; Fax: + 3531402 2447; E-mail: prehn@ rcsi.ie

Keywords: neurogenesis; BH3-only proteins; hippocampus; apoptosis; bim; puma

Abbreviations: BrdU, 5-bromo-2-deoxyuridine; DCX, doublecortin; DG, dentate gyrus; GCL, granular cell layer; LV, lateral ventricle; SGZ, subgranular zone

Received 16.11.09; accepted 19.11.09; Edited by G Melino
} 
Bax-deficient mice have been shown to have greatly reduced apoptosis in neurogenic regions and an increased number of DG cells. ${ }^{10}$ Similarly, it has been shown that overexpression of the anti-apoptotic $\mathrm{Bcl}-2$ protein significantly decreased apoptotic cell death in the GCL of the DG and also led to an increased total number of granule cells. ${ }^{13}$

The pro-apoptotic signalling pathways and upstream initiators of progenitor apoptosis, however, remain largely unknown. Induction of the mitochondrial apoptosis pathway requires the stress-induced activation of the $\mathrm{Bcl}-2$ homology domain 3 (BH3)-only proteins. More than $10 \mathrm{BH} 3-o n l y$ proteins have been identified to date, which vary in their ability to induce apoptosis and in their mechanism of activation and integration in stress-induced apoptosis pathways. Much attention has been drawn to their mechanisms of activation and regulation of apoptosis, but so far it is unknown which BH3-only proteins control the fate of newly generated cells in the adult CNS.

Bim and Puma are two of the most potent BH3-only proteins that have been equally implicated in growth factor withdrawaland matrix-detachment-induced apoptosis. ${ }^{15-20}$ In the following study, we therefore explored the role of Bim and Puma proteins on fate determination of adult-generated cells in the hippocampus, using bim- and puma-deficient animals.

\section{Results}

Bim and puma deficiency increases the number of DCX-positive cells in the adult DG. As it is known that about $80 \%$ of adult generated cells in the hippocampal DG undergo apoptosis and only a small cohort of cells mature into neurons, we were interested in determining the fate of neuronal stem cells in mice deficient in the pro-apoptotic $\mathrm{BH}$-only proteins Bim or Puma. To this end, we labelled brain sections of $w t$, bim $+/-$, bim $-/-$, and puma- $/-$ mice $(n=5)$ at an age of 10-12 weeks with the neuronal progenitor cell marker DCX (Figure 1a) and evaluated the number of DCX-positive cells within the DG (Figure 1b). DCX-positive cells were predominantly found along the $2-3$ cell layer wide SGZ. By their morphology, DCX-expressing cells could be divided into two stages of development, type $2 b$ and type 3 cells. Although younger type $2 \mathrm{~b}$ cells are orientated parallel to the SGZ (Figure 1a, arrowhead), older type 3 cells change their morphology to a horizontal orientation, extend long apical processes into the GCL, and undergo neuronal differentiation (Figure 1a, open arrowhead). Interestingly, bim or puma deficiency resulted in a significant increase in the number of DCX-positive cells (Figure 1b, bim-/$160.4 \pm 9.5$ and puma $-/-143.8 \pm 12.6$ versus wt $71.4 \pm 14.2$ and bim $+1-98.2 \pm 13.5$ per slice), suggesting that the lack of those genes is correlated with an increased presence of neuronal progenitor cells in the adult DG.

\footnotetext{
Bim and puma deficiency increases survival of newly generated cells. To assess whether the increased number of DCX-positive cells was a result of increased proliferation of a progenitor cell population within the SGZ or increased survival of neuronal progenitor cells, mice $(n=5$ per genotype) were injected with $50 \mathrm{mg} / \mathrm{kg}$ 5-bromo-2-
}

deoxyuridine (BrdU) daily on 4 consecutive days. Nuclear incorporation of BrdU was assessed either after $24 \mathrm{~h}(24 \mathrm{~h}$ survival group) or else 7 days later (7-day survival group). The brain cells were stained for BrdU by immunohistochemistry and the number of BrdU-positive cells was evaluated using microscopy (Figure 2a). Cell counts of BrdUpositive cells within the $24 \mathrm{~h}$ survival group revealed no significant difference between different genotypes (data not shown). After 7-day survival, the number of BrdU-positive cells in the wt group was significantly lower compared with the $24 \mathrm{~h}$ wt survival group (Figure $2 \mathrm{~b}, 24 \mathrm{~h}$ survival group $19.2 \pm 1.8$ cells $/ 10 \mu \mathrm{m}$ section versus 7-day survival group $12.4 \pm 2.3$ cells $/ 10 \mu \mathrm{m}$ section, $P=0.027)$. These data suggested that about 35\% of the newly generated cells had succumbed to apoptosis after 7 days. Interestingly, there was no significant reduction in BrdU-positive cells in the bim -/or puma $-/-$ mice after 7 days of survival, (bim $-/-24 \mathrm{~h}$ survival group $29.9 \pm 2.6$ versus 7 -day survival group $27.3 \pm 1.3$, puma $-/-24 \mathrm{~h}$ survival group $24.3 \pm 2.6$ versus 7-day survival group $26.1 \pm 3$, data expressed as cell number $/ 10 \mu \mathrm{m}$ section), suggesting that the newly generated cells were protected by the deficiency of either of the two pro-apoptotic gene knockouts.

There was also a statistically significant difference of BrdU-positive cells in the 7-day survival group of bim-/and puma-/- mice compared with wt and bim $+/-$ animals. No BrdU incorporation was observed in the nuclei of GFAPpositive cells independent of the genotype (Supplementary Figure 4). Taken together, these results suggest that both Bim and Puma regulate the survival of newly generated cells in the adult hippocampus, and suggest that the increase in DCXpositive cells in the bim- and puma-deficient animals was a result of increased survival of neuronal progenitor cells rather than an increase in their proliferation rates.

Apoptosis is decreased in the DG of bim- and pumadeficient mice. To confirm that a diminished apoptotic rate was responsible for the survival of BrdU-positive cells in bim-/- and puma-/- mice, brain sections from mice of all genotypes were terminal deoxynucleotidyl transferasemediated dUTP nick end-labelled (TUNEL) for apoptotic DNA strand breaks (Figure 3a). Positive cells were evaluated within the SGZ and GCL. Statistical analysis revealed that apoptosis was greatly reduced in the DG of bim-/- and puma-/- mice compared with the wt mice (Figure $3 \mathrm{~b}$, $P<0.02)$. Nuclei counts on Hoechst-labelled brain sections also showed that bim-/- and puma-deficient mice tended to have more cells in the DG compared with wt mice; however, this did not reach the level of statistical significance (Supplementary Figure 1). These results further supported our observation that the deficiency in Bim and Puma proteins increased the survival of neuronal precursor cells.

Bim, but not puma, deficiency accelerates neuronal differentiation. We next addressed the question which phenotype BrdU-positive cells presented within bim- and puma-deficient animals after $24 \mathrm{~h}$ and 7 days of survival. Double-labelling with BrdU and the neuronal precursor cell marker DCX or the mature neuronal marker NeuN was performed on sections of bim-/-, bim $+/-$, puma-/-, and 

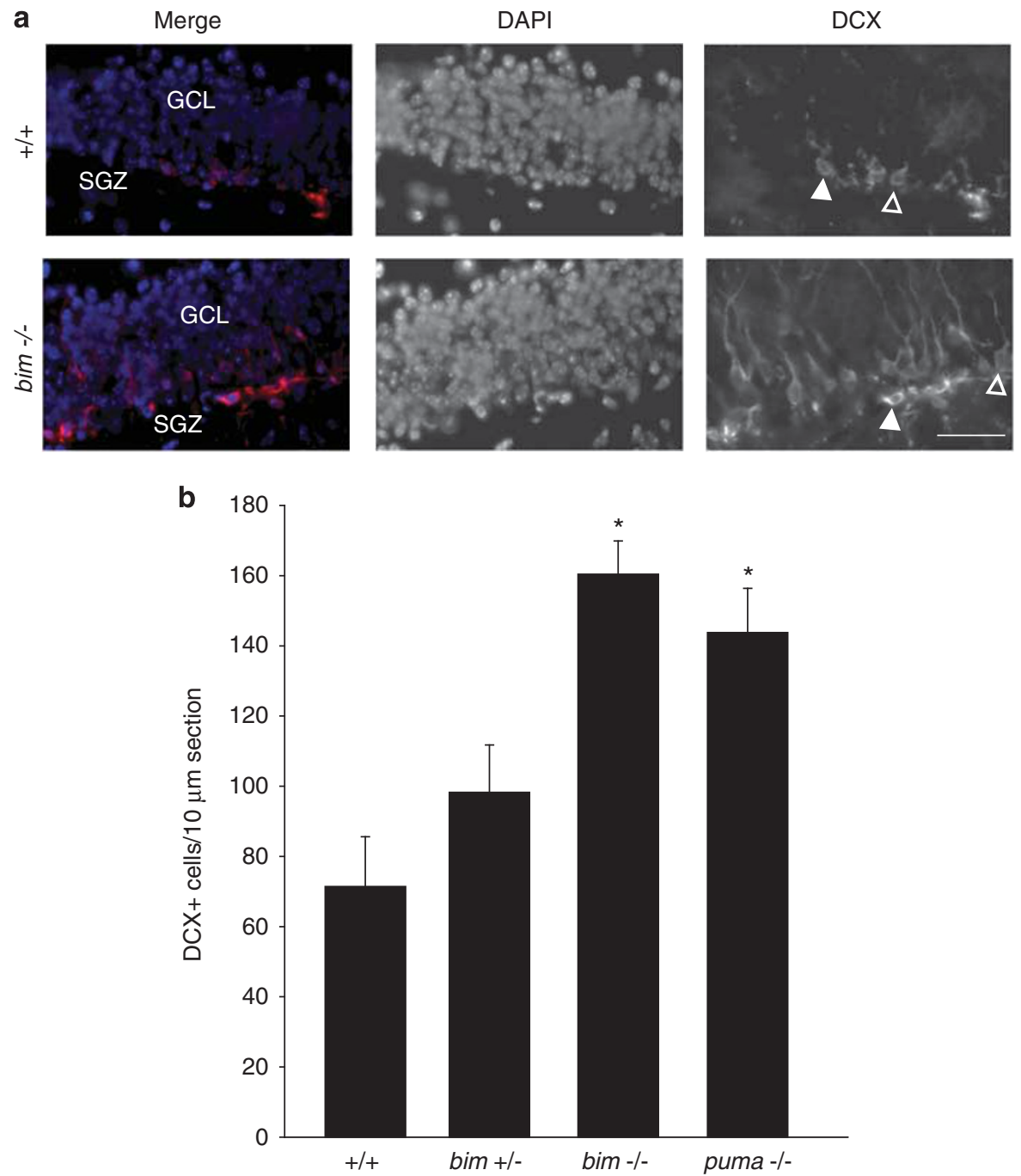

Figure 1 Deficiency in bim or puma results in increased numbers of DCX-expressing cells. (a) 10- to 12-week-old mice were killed, brain slices were stained for DCX (red), and DCX-positive cells were counted in the DG including GCL and SGZ. Morphologically, DCX-positive cells could be differentiated in type $2 b$ (filled arrowhead) and type3 cells (open arrowhead). (b) Statistical analysis revealed a significant increase in DCX-positive cells in bim $-/$ - or puma $-/-$ mice compared with bim $+/-$ or wt mice $(n=5$ mice per genotype). Scale bar $50 \mu \mathrm{m}$. Error bars represent S.E.M. $P \leqslant 0.01$. DCX, doublecortin; DG, dentate gyrus; GCL, granule cell layer; SGZ, subgranular zone

wt mice, and double-labelled versus BrdU-only positive cells were counted in the SGZ and GCL. As expected, $24 \mathrm{~h}$ after BrdU treatment, about $80 \%$ of BrdU-positive cells expressed DCX, indicating that those cells were transiently amplifying progenitor cells (Figure $4 a$ and b). There was no statistically significant difference in the number of BrdU/DCX-positive cells between $w t$ and bim- or puma-deficient mice. At the same time, only a few newly generated cells already expressed NeuN in wt mice (Figure $5 \mathrm{a}$ and c). Interestingly, there was a significant increase in the proportion of cells expressing NeuN in the bim-/- mice compared with the wt mice in the 24-h survival group. This effect also appeared to be gene dose dependent, suggesting that neuronal development was accelerated by the lack of bim (wt $12.8 \% \pm 0.3$ versus bim $+1-20.3 \% \pm 2.4 \quad P<0.05$ and versus bim- $-34 \% \pm 2.1, \quad P<0.001$, data represent $\%$ BrdU/NeuN double-labelled cells of $100 \%$ BrdU-positive cells). It is noted that there was no difference between wt and puma -/- mice in the 24-h survival groups, indicating that the observed effect was specific to bim deficiency.

We further analysed the fate of BrdU-positive cells after 7-day survival. In wt and puma-/- mice, around 32-33\% of BrdU-positive cells expressed DCX. In contrast, we observed a tendency towards a reduced proportion of DCX-positive cells to $24 \%( \pm 4.5)$ in bim $+/-$ and $18 \%$ in bim $-/-( \pm 2.2)$ mice (Figure $6 a$ and Supplementary Figure 2), which, however, did not reach the level of statistical significance compared with wt mice.

After 7 days of survival, NeuN was expressed up to the same percentage of BrdU-positive cells throughout the different genotypes ( $w t \quad 88 \% \pm 1.6$, bim $+1-89 \% \pm 2.2$, bim-/- 91\% \pm 4.2 , puma-/- 89\% \pm 2.2 ) (Figure $6 \mathrm{~b}$ and Supplementary Figure 3). Hence, these data show that Bim has neural functions in addition to the regulation of cell survival, and may inhibit the differentiation of adult-generated neuronal precursor cells in the hippocampus. 
a
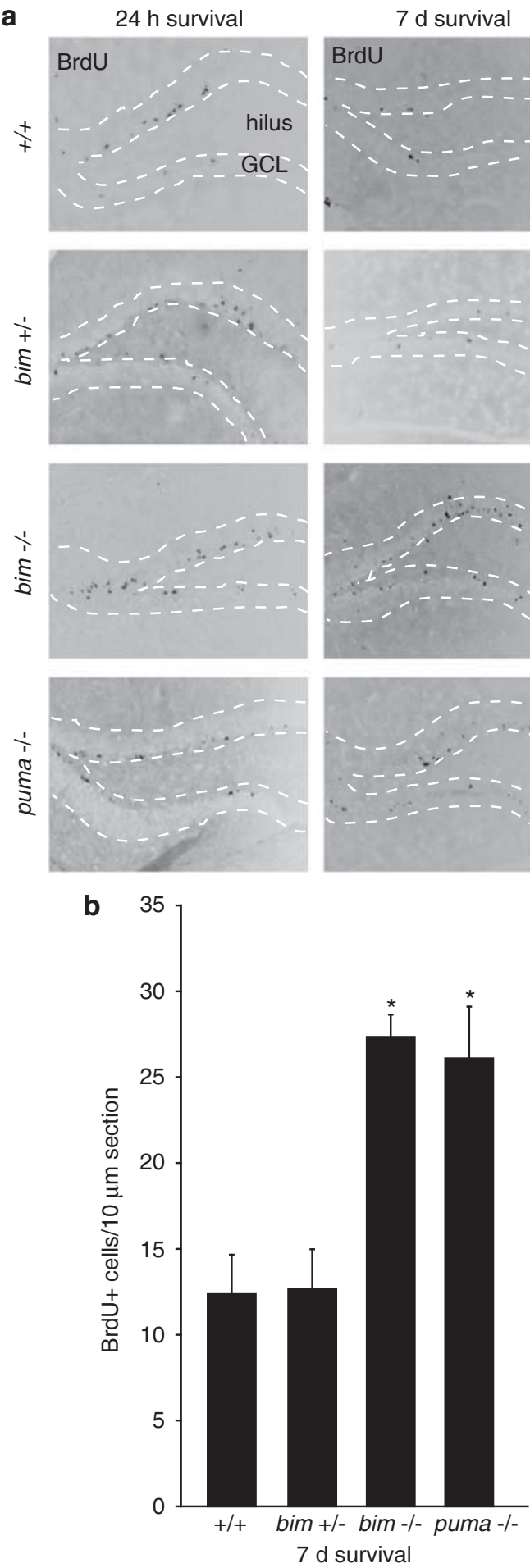

Figure 2 Increased DCX expression is associated with increased survival. (a) Mice were injected with $50 \mathrm{mg} / \mathrm{kg}$ BrdU on 4 consecutive days and BrdU incorporation was analysed $24 \mathrm{~h}$ or 7 days later by immunohistochemistry. (b) Cell counts of BrdU-positive cells within the following 7-day survival revealed that bim-/- and puma-/- mice had significantly higher numbers of BrdU-positive cells compared with wt and bim $+I-$ animals $(P \leqslant 0.01)$ ( $n=5$ mice per genotype). Error bars represent S.E.M. Scale bar $200 \mu \mathrm{m}$ a

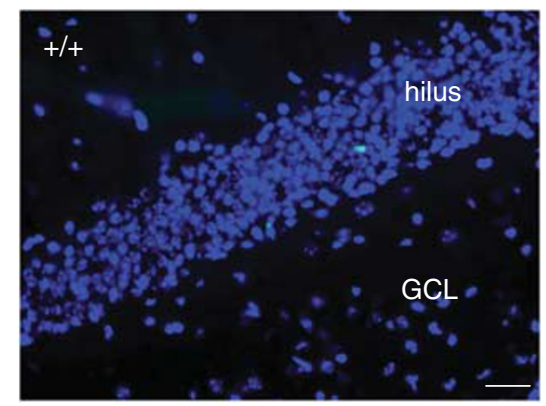

DAPI

TUNEL
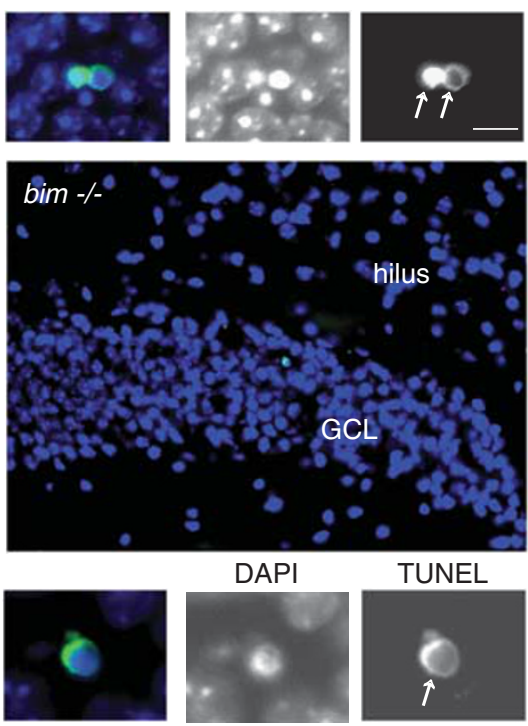

b

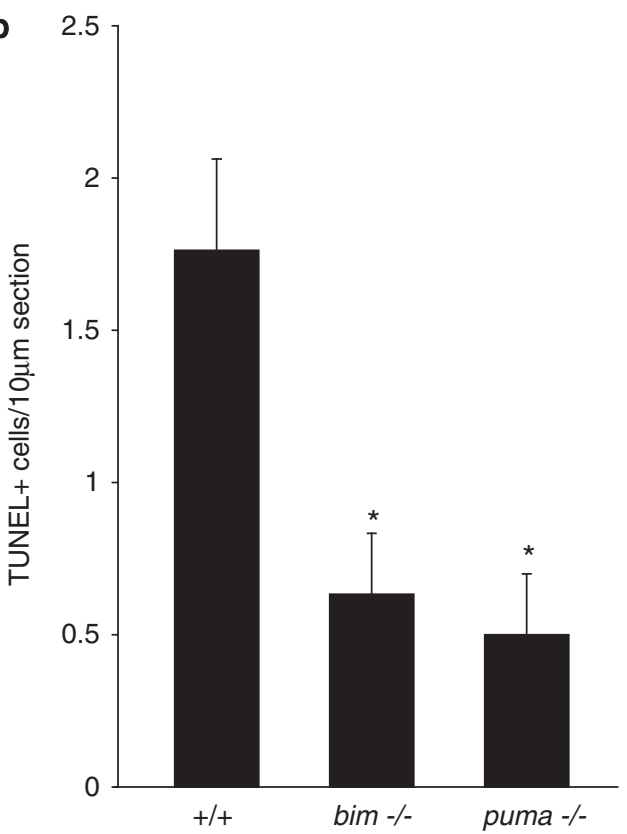

Figure 3 Decreased apoptosis in the dentate gyrus of bim-and puma-deficient mice. (a) Brain slices of knockout and wt mice were analysed for apoptosis by labelling cells with the apoptosis marker TUNEL. Images represent overviews of the dentate gyri for wt and bim-/- mice and higher magnifications of TUNEL-positive cells below the overview. (b) TUNEL-positive cell counts revealed that apoptosis was significantly reduced in the knockout animals $n=5$ mice per genotype). Error bars represent S.E.M. ${ }^{*} P \leqslant 0.02$ 

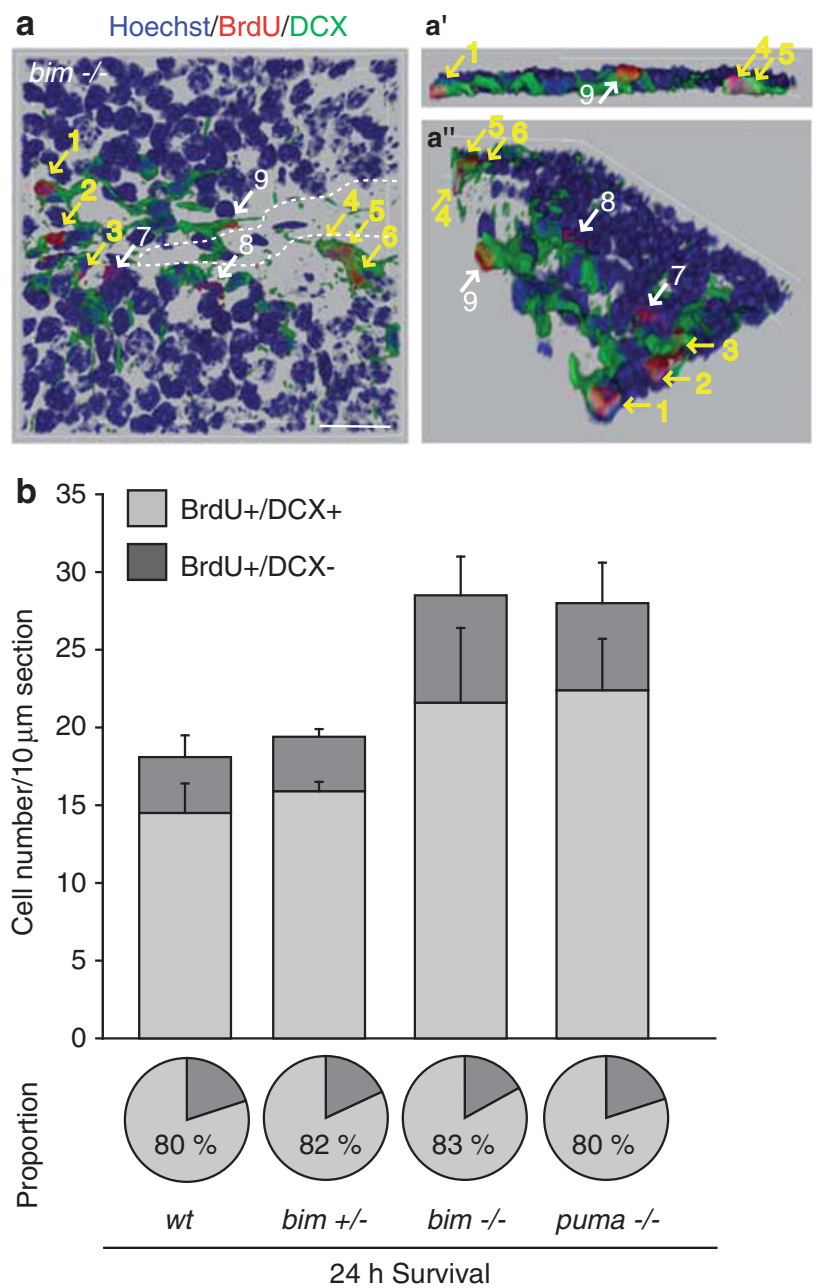

Figure 4 Bim or puma deficiency does not alter the proportion of DCX expression in newly generated cells. (a) Mice were injected with $50 \mathrm{mg} / \mathrm{kg}$ BrdU on 4 consecutive days and killed $24 \mathrm{~h}$ later. Brain slices were stained for BrdU (red) and DCX (green) and colocalisation of the two markers was analysed in the DG by confocal imaging. Yellow arrows indicate double-labelled cells, and white arrows indicate cells positive for BrdU but negative for DCX. Images illustrate the coronal section plane (a), Z-plane of the reconstructed 3D image at the area of the SGZ ( $\left(a^{\prime}\right)$, and the reconstructed 3D image $\left(\mathrm{a}^{\prime \prime}\right)$. Presented is an image of bim-/- DG representative for all genotypes. (b) BrdU +/DCX + and BrdU +/DCX - cells were counted and data are presented as total counts (top panel) and proportional percentages (bottom panel). There was no difference in the total number or percentages of BrdU +/DCX + and BrdU + /DCX - cells between genotypes ( $n=5$ mice per genotype). Error bars represent S.E.M. Scale bar $25 \mu \mathrm{m}$

\section{Discussion}

Apoptosis is an essential process during tissue differentiation and tissue homeostasis. In the nervous system, it is required for establishing optimal levels of connectivity between neuronal and other cell populations, eliminating nonfunctional and aberrant cells or connections, and regulating the size of the progenitor pool. ${ }^{2}$ A massive expansion of neural precursor cells and severe distension of the cranium was observed in mice deficient in proteins essential for the execution phase of apoptosis (caspase-3, caspase-9, and APAF-1). Pathological apoptosis within the adult neural precursor cell population may be linked to cognitive impairments and psychiatric disorders. ${ }^{21}$ In this study, we have determined that two upstream initiators of stressinduced apoptosis, the BH3-only proteins Bim and Puma, have an important role in the survival of newly generated cells in the DG of the adult mouse hippocampus. Furthermore, we show that the $\mathrm{BH} 3-o n l y$ protein Bim may also influence the differentiation of neuronal precursor cells, a separate function unrelated to its regulation of neuronal precursor survival. This finding may add Bim to the growing list of $\mathrm{Bcl}-2$ family proteins that have additional 'daytime' functions other than the regulation of apoptosis.

Deficiency in bim or puma resulted in significantly less apoptosis and increased the survival of neuronal precursor cells in the adult mouse hippocampus. Our data also suggest that their deficiency did not directly influence cell proliferation. The moderate increase in BrdU-positive cells within the 24-h survival group of bim-/- and puma-/- mice, although not statistically significant from wt mice, is most likely explained by a survival effect rather than an enhanced proliferation rate. BrdU was administered over a period of 4 days, and previous studies have shown significant and linear rates of apoptosis in cells of the GCL already occurring within the first days following administration of BrdU. ${ }^{8}$

During adult neurogenesis, a great surplus of cells is generated, of which about $60-80 \%$ die shortly after the birth of a new neuron. ${ }^{7}$ Unlike during embryonic development, expression levels of most members of the pro- and antiapoptotic Bcl-2 protein family are downregulated in the adult brain. ${ }^{22,23}$ However, their expression appears to be retained in neurogenic regions, as shown for $\mathrm{Bcl}-2$ and Bim. ${ }^{24} \mathrm{Bim}$ has previously been shown to be essential for trophic factorand matrix detachment-induced cell death in the nervous system, ${ }^{16}$ stress conditions that may also have a role in the apoptosis of neuronal progenitor cells. The pro-apoptotic activity of Bim is regulated on a transcriptional and posttranslational level, and the mechanism of Bim activation may depend on the type of death stimulus. Bim has been reported to be present in non-apoptotic cells bound to dynein, and the post-translational activation of Bim to involve its phosphorylation by $\mathrm{c}$-jun $\mathrm{N}$-terminal kinase, causing its release from dynein and translocation to mitochondria to induce apoptosis. ${ }^{25}$ However, bim is also transcriptionally activated during trophic factor withdrawal-induced apoptosis. In viable cells, the binding of growth factors to their tyrosine kinase receptors results in the activation serine/threonine kinases of the Akt family. ${ }^{26}$ Akt phosphorylates members of the FoxO transcription factor family, which causes FoxO to relocate to the cytosol for proteasomal degradation. Trophic factor withdrawal leads to FoxO dephosphorylation and transcription of its target genes, including bim. Regulation of bim expression may also involve E2F1-dependent gene de-repression in neurons deprived of growth factors. ${ }^{27}$ In this context, it is also interesting to mention that E2F1-/- mice show less hippocampal progenitor proliferation, less postnatal neurogenesis, and less apoptosis. ${ }^{28}$

In contrast to Bim, Puma appears to be activated predominantly by transcriptional mechanisms. Puma is a well-established p53 target gene, ${ }^{29}$ but can also activate apoptosis independent of p53. ${ }^{18,20,30-32}$ Similar to bim, the transcription of puma can also be activated by E2F1, ${ }^{33}$ 
and Puma has been shown to contribute to trophic factor withdrawal-induced apoptosis in non-neuronal cells. ${ }^{18,30}$ Puma deficiency has previously been shown to protect cultured telencephalic neural precursor cells from p53-dependent genotoxic cell death. ${ }^{20,31}$ Our data indicate that puma is also required for the physiological cell death of neuronal progenitor cells in vivo.

Consistent with our results, the study by Sun et al. ${ }^{10}$ showed that deficiency of the pro-apoptotic protein Bax resulted in a complete absence of apoptosis within the DG as well as an increased occurrence of cells positive for a Hoechst/BrdU/NeuN

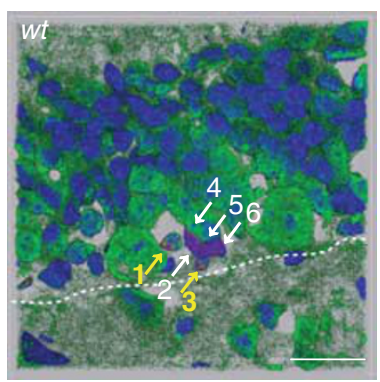

b

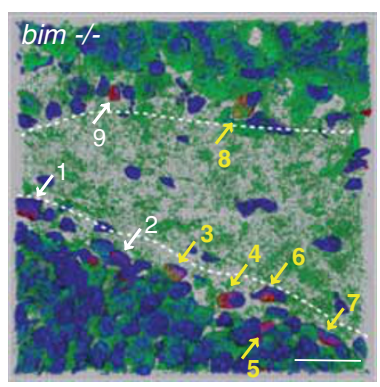

$a^{\prime}$

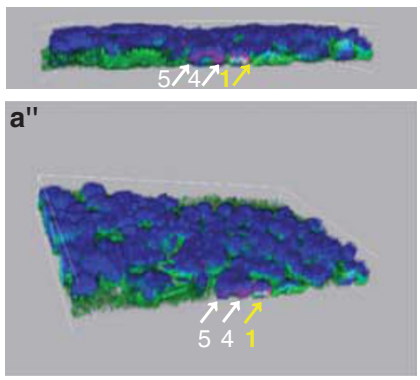

$\mathbf{b}^{\prime}$

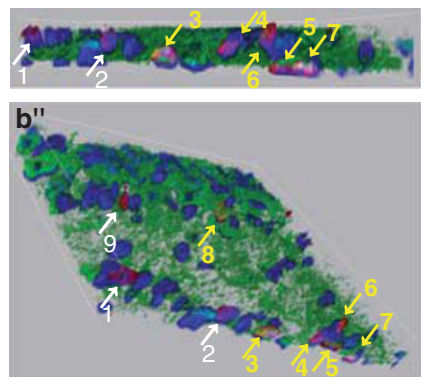

C

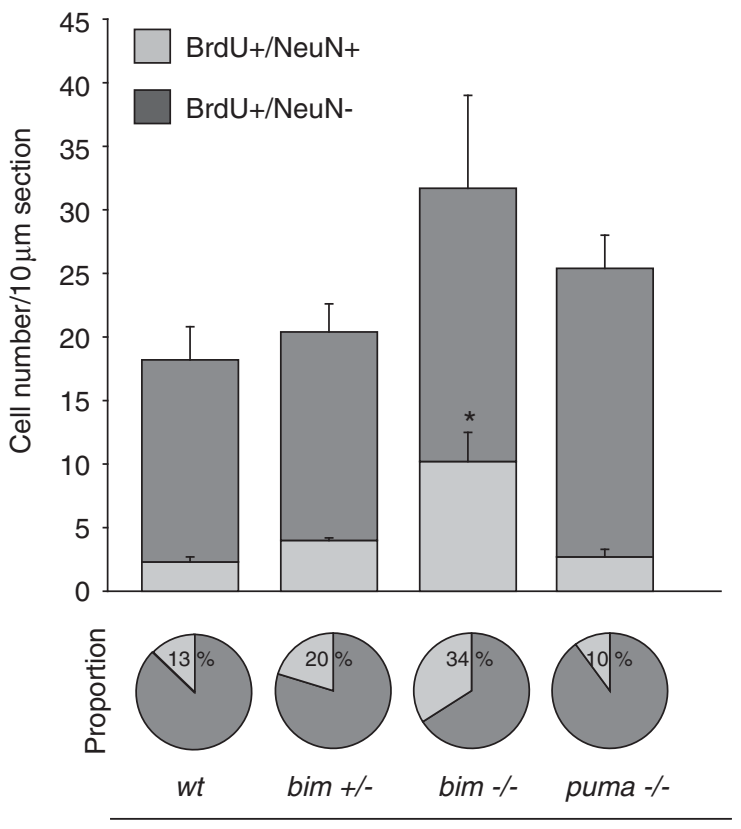

24 h Survival neuronal progenitor markers in vivo, suggesting a dramatic improvement of progenitor apoptosis. In our study, the levels of TUNEL-positive cells in the DG of bim-/- or puma-/mice were reduced by about two-thirds. This incomplete protection observed in our study might highlight the upstream and potentially distinct roles of Bim and Puma within stressinduced apoptosis signalling cascades. A double knockout for bim and puma could possibly address the question whether other BH3-only proteins or alternative apoptosis pathways contribute to neuronal progenitor apoptosis; however, crossbreeding of bim-and puma-deficient mice results in significant embryonic lethality (authors' unpublished data).

It is noted that in this work we present evidence that bim deficiency results in a gene dose-dependent increase in the proportion of NeuN-positive cells within the pool of cells that have recently undergone mitosis, suggesting that physiological Bim levels inhibit neuronal differentiation. Alternative functions of $\mathrm{Bcl}-2$ family proteins other than cell death regulation have been reported for several members. Earlier studies have implicated $\mathrm{Bcl}-2$ in proliferation and neuronal differentiation. ${ }^{34} \mathrm{Bcl}-2$ has also been suggested to affect cell cycle re-entry from $\mathrm{G}_{0}$ and to prolong $\mathrm{G}_{1}$ phase. It is noted that $\mathrm{Bcl}-2$ also promoted axonal outgrowth of retinal ganglion cells, and that this mechanism was shown to be independent from anti-apoptosis. ${ }^{35}$ Interestingly, the effect of Bcl-2 on axonal outgrowth was shown to be dose dependent, similar to our observation on the effect of different gene doses of bim on neuronal differentiation. Bim binds to and 'neutralises' Bcl-2. It is tempting to speculate that endogenous Bim levels determine the amount of sequestered Bcl-2, and in doing so influence neuronal differentiation or axonal outgrowth.

Interestingly, such an effect was not observed in the puma-/- mice, despite having a similar effect on cell survival and an otherwise identical genetic background. Both Bim and Puma have been shown to sequester Bcl-2 family members equally. ${ }^{36}$ Therefore, Bim may have a specific and direct effect on neuronal differentiation. NeuN first appears in neuronal nuclei at a time point close to its withdrawal from the cell cycle. Evidence has been presented that although phosphorylated Bim can induce cell death in response to stress, it may also

Figure 5 Bim deficiency accelerates differentiation of newly generated cells into neuronal phenotype. (a and $\mathbf{b}$ ) Mice were injected with $50 \mathrm{mg} / \mathrm{kg} \mathrm{BrdU}$ on 4 consecutive days and killed $24 \mathrm{~h}$ later. Brain slices were stained for BrdU (red) and NeuN (green), and colocalisation of the two markers was analysed in the DG by confocal imaging. Yellow arrows indicate double-labelled cells, and white arrows indicate cells positive for BrdU but negative for NeuN. In bim - / - mice, more BrdUpositive cells expressed NeuN (it is noted that there are more yellow than white arrows) compared with wt or puma-/- mice. Images illustrate the coronal section plane (a and $\mathbf{b}), Z$-plane of the reconstructed 3D image at the area of the SGZ $\left(a^{\prime}, b^{\prime}\right)$, and the reconstructed $3 D$ image $\left(a^{\prime \prime}, b^{\prime \prime}\right)$ representing bim $-/-\left(b-b^{\prime \prime}\right)$ and wt $\left(\mathrm{a}-\mathrm{a}^{\prime \prime}\right) \mathrm{DG}$. (c) BrdU + /NeuN + and BrdU + /NeuN - cells were counted and data are presented as total counts (top panel) and percentages (bottom panel). Bim-/ - mice had significantly more BrdU $+/ \mathrm{NeuN}+$ cells compared with $w t$ $(P<0.007)$, bim $+1-(P 0.027)$, and puma $-/-(P<0.01)$ in total cell counts. A comparison of the ratios of $\mathrm{BrdU}+/ \mathrm{NeuN}+$ and $\mathrm{BrdU}+/ \mathrm{NeuN}-$ cells between genotypes showed that bim $-/-$ had significantly more BrdU $+/ \mathrm{NeuN}+$ cells than wt $(P<0.05)$ and puma $-/-(P<0.05)$ mice. Bim $+/-$ mice also had significantly more $\mathrm{BrdU}+/ \mathrm{NeuN}+$ cells compared with wt $(P<0.05)$ and puma-/$(P<0.01)$. Error bars represent S.E.M. $n=5$ mice per genotype). Scale bar $25 \mu \mathrm{m}$. 
facilitate the ordered execution of mitosis. ${ }^{37}$ It is noted that Bim phosphorylation during mitosis occurs downstream of bFGF signalling, and that the latter is necessary and sufficient to maintain multipotency and promote the proliferation of neuronal progenitor cells in the adult hippocampus. ${ }^{38}$ Although it is possible that the effect on neuronal differentiation is specific to Bim, the difference between Bim and Puma can also be explained by the fact that Bim is physiologically
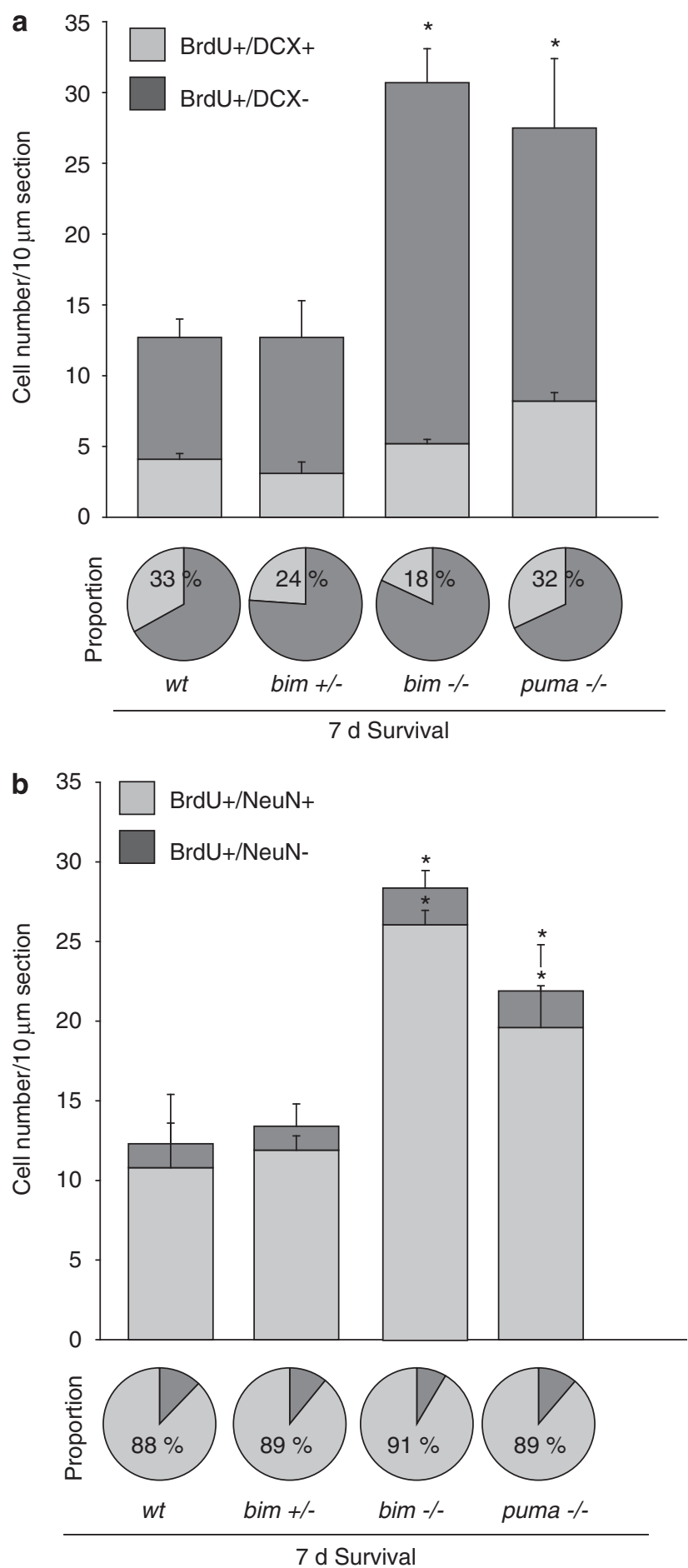

expressed and detectable in the neurogenic regions of the brain, whereas Puma may be absent unless transcriptionally induced during stress-induced apoptosis.

In conclusion, we identified the $\mathrm{BH}$-only proteins Bim and Puma to be implicated in the regulation of survival of newly generated cells in the hippocampal DG of adult mice, and provide new evidence for a role of the $\mathrm{BH}$-only protein Bim in the process of neuronal differentiation. Further research will be necessary to reveal the molecular mechanisms involved in this process. Uncovering the mechanisms involved in survival and/or differentiation of cells generated in the adult brain will be of benefit to understand how the newly generated cells might be used for regeneration of damaged brain tissue.

\section{Materials and Methods}

Animals. Animal experiments were carried out under licence from the Department of Health and Children (Ireland) and procedures were reviewed and approved by the Research Ethics Committee of the Royal College of Surgeons in Ireland. All efforts were made to minimise animal use and discomfort. Animals were housed in a specialised animal facility (five per cage) and had ad libitum access to standard food and water and a light/dark cycle of $12 \mathrm{~h}$. At the age of 10 weeks, a total number of 10 male mice per genotype (bim-/-, bim $+/-$, puma- - ), and wild-type $(w t)$ animals of the same genetic background (C57BL/6) were used in this study. The gene-deficient animals were kindly provided by Prof Andreas Strasser (Walter \& Eliza Hall Institute of Medical Research, Melbourne, Australia) and genotyped as previously described. ${ }^{19,39}$ Bim-/- mice were generated using W9.5 ES cells; puma -/- mice were generated using Bruce4 ES cells. ES cell clones were microinjected into $\mathrm{C} 57 \mathrm{BL} / 6$ blastocysts and mice were back-crossed into the C57BL/6 background.

BrdU administration. 5-bromo-2-deoxyuridine (BrdU, Sigma-Aldrich, Dublin, Ireland) was prepared at $10 \mathrm{mg} / \mathrm{ml}(65 \mathrm{mM})$ in $0.9 \%$ saline and injected intraperitoneally at $5 \mathrm{ml} / \mathrm{kg}$ to achieve an effective dose of $50 \mathrm{mg} / \mathrm{kg}$ as previously described. ${ }^{40}$ At the age of 10 weeks, mice received one injection daily on 4 consecutive days. To assess proliferation, five animals of each genotype were killed $24 \mathrm{~h}$ after the last BrdU injection. A second set of five animals per genotype were killed 7 days later to study survival and differentiation of the newly generated cells.

Tissue preparation. Animals were killed by anaesthesia and transcardial perfusion with $20 \mathrm{ml}$ ice-cold PBS followed by $20 \mathrm{ml} 4 \%$ paraformaldehyde (PFA). Each solution was injected into the heart with an injection rate of $4 \mathrm{ml} / \mathrm{min}$. Brains were removed, post-fixed in $4 \%$ PFA for $12 \mathrm{~h}$ at $4{ }^{\circ} \mathrm{C}$, cryo-protected in $30 \%$

Figure 6 After 7-day survival, the proportion of newly generated cells expressing DCX is slightly decreased in bim-/- and puma-/- mice, whereas NeuN expression shows no difference between genotypes. (a) Mice were injected with $50 \mathrm{mg} / \mathrm{kg}$ BrdU on 4 consecutive days and killed 7 days later. Brain sections were analysed for BrdU and DCX colabelling. BrdU + /DCX + and BrdU + /DCXcells were counted. Data are presented as total counts (top panel) and proportional percentages (bottom panel). Note that bim $-/$ - and puma $-/-$ mice showed a significant increase in total $\mathrm{BrdU}+$ counts. There was no significant difference in the proportion of BrdU + /DCX + to BrdU + /DCX- cells; bim - / - mice tended to have reduced numbers of double-positive cells (bim-/- versus wt $P=0.1$, bim $-/$ - versus puma $-/-P=0.2$ ) when comparing the ratios of BrdU $+/ D C X+$ with $\mathrm{BrdU}+/ \mathrm{DCX}$ - cells between the genotypes. (b) Brain sections were analysed for BrdU and NeuN colocalisation in the DG. BrdU $+/ \mathrm{NeuN}+$ and BrdU +1 NeuN - cells were counted and data are presented as total counts (top panel) and percentages (bottom panel). Note that bim $-/-$ and puma $-/-$ mice had significantly more total BrdU + (including NeuN + and NeuN - cells) and total $\mathrm{BrdU}+/ \mathrm{NeuN}+$ cells $(\mathrm{BrdU}+/ \mathrm{NeuN}+$ cells: bim-/ - versus wt $P=0.002$, bim $-/$ - versus bim $+/-P=0.003$, puma $-/$ - versus WT $P=0.04$, comparing the total number of cells). There was no difference in the ratio of BrdU $+/ \mathrm{NeuN}+$ to $\mathrm{BrdU}+/ \mathrm{NeuN}-$ cells between genotypes ( $n=5$ mice per genotype). Error bars represent S.E.M. Scale bar $25 \mu \mathrm{m}$ 
sucrose/PBS until equilibrated, and frozen at $-20^{\circ} \mathrm{C}$. The brains were stored in $-80^{\circ} \mathrm{C}$ until further processing.

For analysis, brains were sliced into $10 \mu \mathrm{m}$ coronal sections on a cryostat (Leica, Wetzlar, Germany) at $-20^{\circ} \mathrm{C}$. As the starting point for collection, an anteriorposterior coordinate of $-1.4 \mathrm{~mm}$ (from Bregma according to the Mouse Brain in Stereotaxic Coordinates, Paxinos and Franklin, Academic Press) was chosen. Sets of four consecutive brain slices were collected every $40 \mu \mathrm{m}$ until the anteriorposterior coordinate of $-2.4 \mathrm{~mm}$ (from Bregma) was reached. Brain slices belonging to one set of four consecutive slices were stained for the indicated marker proteins by immunofluorescence.

\section{Immunofluorescence}

BrdU labelling and BrdU/NeuN double-labelling. For BrdU labelling and $\mathrm{BrdU} /$ NeuN double-labelling, brain slices were washed in PBS, DNA was denatured with $2 \mathrm{~N} \mathrm{HCl}$ for $20 \mathrm{~min}$ at $37^{\circ} \mathrm{C}$, and neutralised with $0.1 \mathrm{M}$ borax buffer (pH9) for $20 \mathrm{~min}$ at room temperature. Following washing, the tissue was incubated with $10 \%$ fetal calf serum for $1 \mathrm{~h}$ at room temperature. Primary antibodies (rat anti-BrdU, AbD Serotec, Oxford, UK, 1/300; mouse anti-NeuN, Chemicon, Cork, Ireland, 1/500 or mouse anti-BrdU, BD Bioscience, Oxford, UK, 1/100) were diluted in blocking solution and applied overnight at $4{ }^{\circ} \mathrm{C}$. After washing, the respective secondary antibodies (goat anti-rat 488, goat anti-mouse 568; goat anti-mouse 488, goat antirabbit 568, all Molecular Probes (Eugene, OR, USA), 1/1000 in blocking solution) were applied for $2 \mathrm{~h}$ at room temperature.

Doublecortin labelling. For labelling of DCX, brain slices were washed in PBS before incubation with $0.1 \%$ Triton X-100/PBS for 15 min on ice. Following washing in PBS, slices were blocked in $5 \%$ horse serum and $0.3 \%$ Triton X-100/ PBS for $30 \mathrm{~min}$ at room temperature. Slices were again washed in PBS and goat anti-DCX antibody (Santz Cruz, 1/100, Santa Cruz Biotech, Heidelberg, Germany) was applied in blocking solution overnight at $4{ }^{\circ} \mathrm{C}$. After washing the secondary antibody, donkey-anti-goat rhodamine conjugated (Jackson Immunoresearch, Plymouth, PA, USA, 1/1000) was applied for $2 \mathrm{~h}$ at room temperature.

BrdU and doublecortin double-labelling. For double-labelling of BrdU and doublecortin (DCX), a combination of the protocols described above was used. First, brain slices were stained for DCX using goat anti-DCX and donkey-anti-goat fluorescein conjugated. Following washing, slices were then prepared for BrdU labelling and mouse anti-BrdU (BD Bioscience, 1/100) was used as primary antibody and goat anti-mouse 568 (Molecular probes, 1/1000) was used as secondary antibody.

Slices were embedded in DAPI-containing mounting media or incubated with Hoechst 33342, and then washed and mounted in FluorSave Reagent (Calbiochem, Merck Bioscience, Nottingham, UK).

Control experiments were performed by incubation with secondary antibodies only and no unspecific staining was observed.

DeadEnd fluorimetric TUNEL staining. Apoptotic cell death in the hippocampal DG was analysed using the DeadEnd Fluorimetric TUNEL System (Promega, Medical Supply Ltd, Dublin, Ireland). After washing in PBS, the tissue slices were permeabilised in 3\% Triton X-100/PBS for 20 min, washed with $0.1 \%$ Triton X-100/PBS, and incubated with equilibration buffer for $15 \mathrm{~min}$ at room temperature. After equilibration, the TUNEL solution was applied to the slices for $90 \mathrm{~min}$ at $37^{\circ} \mathrm{C}$. The enzymatic reaction was terminated with $2 \times \mathrm{SSC}$ for $15 \mathrm{~min}$ at room temperature. The slices were washed $3 \times 5 \mathrm{~min}$ in $0.1 \%$ Triton $\mathrm{X}-100 / \mathrm{PBS}$, $2 \times 5 \mathrm{~min}$ in PBS and $1 \times 5 \mathrm{~min}$ in $\mathrm{dH}_{2} \mathrm{O}$, and mounted with DAPI-containing medium.

Data quantification and statistical analysis. All images were acquired with an Eclipse TE 300 inverted microscope (Nikon, Surrey, UK) and a $40 \times$ oil objective with the SPOT imaging software (Diagnostic instruments, Sterling Heights, MI, USA) or by confocal laser scanning microscopy using the LSM 710 confocal microscope (Zeiss, Jena, Germany) and a $40 \times$ oil objective (NA=1.3). Images were further processed with Image $\mathrm{J}$ software (NIH, Baltimore, MA, USA) or the Zeiss Zen software package. Series of optical sections of tissue slices labelled for total nuclear DNA (DAPI), proteins (NeuN or DCX, Alexa 488-conjugated antibodies), and replicating DNA (BrdU detected using antibodies conjugated with Cy5) were subjected to blind deconvolution (25 iterations, noise suppression set to 'medium', AutoQuant, MediaCybernetics Inc., Bethesda, MD, USA). The data were visualised using alpha-blending projection with opacity linearly proportional to voxel intensity. The opacity curve was adjusted separately for each colour. The projections were generated with eight samples per voxel and 0.5 voxel radius Gaussian filtering. The projections were generated in directions perpendicular to $x y$ $x z$ planes or at an angle from 30 to 60 degrees to the xy plane. In the latter two cases, parts of the volume were removed to show nuclei labelled with BrdU. Processing and visualisation of the confocal data were carried out using AutoDeblur CWF ver. 2.1.3 (Media Cybernetics Inc.) or Volocity ver. 3.2. (PerkinElmer, Coventry, UK).

Cell counting was performed in a blinded manner on images registered with Eclipse TE 300 inverted microscope (Nikon) and a $40 \times$ oil objective. BrdU, DCX, or TUNEL-positive cells or cells double positive for BrdU and DCX or NeuN were counted in the DG of the hippocampus. Only cells within the SGZ and the GCL were included; cells without direct contact to the DG (located within the hilus) were excluded from counting.

Data are given as mean \pm S.E.M. Data were tested for normal distribution using the Shapiro-Wilk test of normality. Statistical significance of differences between means was evaluated by one-way ANOVA followed by Tukey's test for parametric or Mann-Whitney U-test for non-parametric data, and in all cases $P<0.05$ was considered significant.

\section{Conflict of interest}

The authors declare no conflict of interest.

Acknowledgements. We thank Ina Kögel for excellent technical assistance. This research was supported by grants from Science Foundation Ireland to JHMP (03/RP1/B344; 08/IN1/1949), and by the National Biophotonics and Imaging Platform Ireland (Higher Education Authority).

1. Kaplan MS, Hinds JW. Neurogenesis in the adult rat: electron microscopic analysis of light radioautographs. Science 1977; 197: 1092-1094.

2. Cameron HA, McKay RD. Adult neurogenesis produces a large pool of new granule cells in the dentate gyrus. J Comp Neurol 2001; 435: 406-417.

3. Brandt MD, Jessberger S, Steiner B, Kronenberg G, Reuter K, Bick-Sander A et al. Transient calretinin expression defines early postmitotic step of neuronal differentiation in adult hippocampal neurogenesis of mice. Mol Cell Neurosci 2003; 24: 603-613.

4. Seri B, Garcia-Verdugo JM, Collado-Morente L, McEwen BS, Alvarez-Buylla A. Cell types, lineage, and architecture of the germinal zone in the adult dentate gyrus. J Comp Neurol 2004; 478: 359-378.

5. Altman J, Bayer SA. Migration and distribution of two populations of hippocampal granule cell precursors during the perinatal and postnatal periods. J Comp Neurol 1990; 301: 365-381.

6. Stanfield BB, Trice JE. Evidence that granule cells generated in the dentate gyrus of adult rats extend axonal projections. Exp Brain Res 1988; 72: 399-406.

7. Biebl M, Cooper CM, Winkler J, Kuhn HG. Analysis of neurogenesis and programmed cell death reveals a self-renewing capacity in the adult rat brain. Neurosci Lett 2000; 291: 17-20.

8. Dayer AG, Ford AA, Cleaver KM, Yassaee M, Cameron HA. Short-term and long-term survival of new neurons in the rat dentate gyrus. J Comp Neurol 2003; 460: 563-572.

9. Herrup K, Busser JC. The induction of multiple cell cycle events precedes target-related neuronal death. Development 1995; 121: 2385-2395.

10. Sun W, Winseck A, Vinsant S, Park OH, Kim H, Oppenheim RW. Programmed cell death of adult-generated hippocampal neurons is mediated by the proapoptotic gene Bax. J Neurosci 2004; 24: 11205-11213.

11. Kempermann G, Kuhn HG, Gage FH. More hippocampal neurons in adult mice living in an enriched environment. Nature 1997; 386: 493-495.

12. Madsen TM, Treschow A, Bengzon J, Bolwig TG, Lindvall O, Tingstrom A. Increased neurogenesis in a model of electroconvulsive therapy. Biol Psychiatry 2000; 47: 1043-1049.

13. Kuhn HG, Biebl M, Wilhelm D, Li M, Friedlander RM, Winkler J. Increased generation of granule cells in adult Bcl-2-overexpressing mice: a role for cell death during continued hippocampal neurogenesis. Eur J Neurosci 2005; 22: 1907-1915.

14. Lovell JF, Billen LP, Bindner S, Shamas-Din A, Fradin C, Leber B et al. Membrane binding by tBid initiates an ordered series of events culminating in membrane permeabilization by Bax. Cell 2008; 135: 1074-1084.

15. Reginato MJ, Mills KR, Paulus JK, Lynch DK, Sgroi DC, Debnath J et al. Integrins and EGFR coordinately regulate the pro-apoptotic protein Bim to prevent anoikis. Nat Cell Biol 2003; 5: 733-740.

16. Putcha GV, Moulder KL, Golden JP, Bouillet P, Adams JA, Strasser A et al. Induction of $\mathrm{BIM}$, a proapoptotic BH3-only BCL-2 family member, is critical for neuronal apoptosis. Neuron 2001; 29: 615-628. 
17. Whitfield J, Neame SJ, Paquet L, Bernard O, Ham J. Dominant-negative c-Jun promotes neuronal survival by reducing BIM expression and inhibiting mitochondrial cytochrome $\mathrm{C}$ release. Neuron 2001; 29: 629-643.

18. Han J, Flemington C, Houghton AB, Gu Z, Zambetti GP, Lutz RJ et al. Expression of bbc3, a pro-apoptotic $\mathrm{BH} 3$-only gene, is regulated by diverse cell death and survival signals. Proc Natl Acad Sci USA 2001; 98: 11318-11323.

19. Bouillet P, Metcalf D, Huang DC, Tarlinton DM, Kay TW, Kontgen F et al. Proapoptotic $\mathrm{Bcl}-2$ relative Bim required for certain apoptotic responses, leukocyte homeostasis, and to preclude autoimmunity. Science 1999; 286: 1735-1738.

20. Akhtar RS, Geng Y, Klocke BJ, Latham CB, Villunger A, Michalak EM et al. BH3-only proapoptotic $\mathrm{Bcl}-2$ family members Noxa and Puma mediate neural precursor cell death $J$ Neurosci 2006; 26: 7257-7264.

21. Monje ML, Mizumatsu S, Fike JR, Palmer TD. Irradiation induces neural precursor-cell dysfunction. Nat Med 2002; 8: 955-962.

22. Vekrellis K, McCarthy MJ, Watson A, Whitfield J, Rubin LL, Ham J. Bax promotes neuronal cell death and is downregulated during the development of the nervous system. Development 1997; 124: 1239-1249.

23. Krajewska M, Mai JK, Zapata JM, Ashwell KW, Schendel SL, Reed JC et al. Dynamics of expression of apoptosis-regulatory proteins Bid, Bcl-2, Bcl-X, Bax and Bak during development of murine nervous system. Cell Death Differ 2002; 9: 145-157.

24. Madden SD, Donovan M, Cotter TG. Key apoptosis regulating proteins are down-regulated during postnatal tissue development. Int J Dev Biol 2007; 51: 415-423.

25. Lei K, Davis RJ. JNK phosphorylation of Bim-related members of the Bcl2 family induces Bax-dependent apoptosis. Proc Natl Acad Sci USA 2003; 100: 2432-2437.

26. Cantley LC. The phosphoinositide 3-kinase pathway. Science 2002; 296: 1655-1657.

27. Biswas SC, Liu DX, Greene LA. Bim is a direct target of a neuronal E2F-dependent apoptotic pathway. J Neurosci 2005; 25: 8349-8358.

28. Cooper-Kuhn CM, Vroemen M, Brown J, Ye H, Thompson MA, Winkler J et al. Impaired adult neurogenesis in mice lacking the transcription factor E2F1. Mol Cell Neurosci2002; 21: 312-323.

29. Yu J, Wang Z, Kinzler KW, Vogelstein B, Zhang L. PUMA mediates the apoptotic response to p53 in colorectal cancer cells. Proc Natl Acad Sci USA 2003; 100: 1931-1936.

30. You H, Pellegrini M, Tsuchihara K, Yamamoto K, Hacker G, Erlacher M et al. FOXO3adependent regulation of Puma in response to cytokine/growth factor withdrawal. J Exp Med 2006; 203: 1657-1663.
31. Akhtar RS, Geng Y, Klocke BJ, Roth KA. Neural precursor cells possess multiple p53-dependent apoptotic pathways. Cell Death Differ 2006; 13: 1727-1739.

32. Concannon CG, Koehler BF, Reimertz C, Murphy BM, Bonner C, Thurow N et al. Apoptosis induced by proteasome inhibition in cancer cells: predominant role of the p53/PUMA pathway. Oncogene 2007; 26: 1681-1692.

33. Hershko T, Ginsberg D. Up-regulation of Bcl-2 homology $3(\mathrm{BH} 3)$-only proteins by E2F1 mediates apoptosis. J Biol Chem 2004; 279: 8627-8634.

34. O'Reilly LA, Harris AW, Tarlinton DM, Corcoran LM, Strasser A. Expression of a bcl-2 transgene reduces proliferation and slows turnover of developing $B$ lymphocytes in vivo. J Immunol 1997; 159: 2301-2311.

35. Chen DF, Schneider GE, Martinou JC, Tonegawa S. Bcl-2 promotes regeneration of severed axons in mammalian CNS. Nature 1997; 385: 434-439.

36. Marani M, Tenev T, Hancock D, Downward J, Lemoine NR. Identification of novel isoforms of the $\mathrm{BH} 3$ domain protein Bim which directly activate Bax to trigger apoptosis. Mol Cell Biol 2002; 22: 3577-3589.

37. Graos M, Almeida AD, Chatterjee S. Growth-factor-dependent phosphorylation of Bim in mitosis. Biochem J 2005; 388 (Part 1): 185-194.

38. Yoshimura S, Takagi Y, Harada J, Teramoto T, Thomas SS, Waeber C et al. FGF-2 regulation of neurogenesis in adult hippocampus after brain injury. Proc Natl Acad Sci USA 2001; 98: 5874-5879.

39. Villunger A, Michalak EM, Coultas L, Mullauer F, Bock G, Ausserlechner MJ et al. p53- and drug-induced apoptotic responses mediated by $\mathrm{BH} 3$-only proteins puma and noxa. Science 2003; 302: 1036-1038.

40. Gage FH, Coates PW, Palmer TD, Kuhn HG, Fisher LJ, Suhonen JO et al. Survival and differentiation of adult neuronal progenitor cells transplanted to the adult brain. Proc Natl Acad Sci USA 1995; 92: 11879-11883.

Cell Death and Disease is an open-access journal published by Nature Publishing Group. This article is licensed under a Creative Commons Attribution-Noncommercial-No Derivative Works 3.0 License. To view a copy of this license, visit http:// creativecommons.org/licenses/by-nc-nd/3.0/

Supplementary Information accompanies the paper on Cell Death and Disease website (http://www.nature.com/cddis) 